\title{
THE IMPORTANCE OF PHYSICAL ACTIVITY IN COLORECTAL CANCER PREVENTION
}

\author{
NATAŠA ANTOLJAK \\ School of Medicine, University of Zagreb and Croatian Institute of Public Health, \\ School of Public Health Andrija Štampar, Zagreb, Croatia
}

\begin{abstract}
Summary
Colorectal cancer is the second most common malignant neoplasm and the second cause of death from malignancies in both sexes. In 2017, 3689 people were diagnosed in the Republic of Croatia. Two thousand ninety-five people died of colorectal cancer in 2019. Colorectal cancer is preventable, and it appears that smoking and obesity are factors that affect its onset. Physical inactivity is closely related to obesity, and the question is whether it can be an independent predictor of colon cancer. We searched the literature on Pubmed for the past five years, including systematic reviews and meta-analyses on the association between physical activity and colon cancer incidence. Studies are methodologically diverse and involve different approaches. In most observational studies, greater physical activity is associated with a lower incidence of colon cancer, while in the interventional studies, results were more diverse. In general, smoking tobacco products has a much greater effect on colon cancer development, but physical activity is linked to the onset of the disease and should be one of the prevention measures.
\end{abstract}

KEYWORDS: colorectal cancer, physical activity, causal inference

\section{INTRODUCTION}

Colorectal cancer (abbrev. CRC) is the second most common cause of malignancy in both sexes (1). In the Republic of Croatia, this disease affects about 3500 people of both sexes a year were about 2100 die, a stable trend in recent years. In 2017, we diagnosed 3659 persons with CRC. In 2019, 2095 people died from this disease (3.8\% of all deaths), which is the sixth leading cause of death in Croatia (2). Most patients do not have an inherited predisposition to cancer, and according to the latest data, young people born after the year 2000 have a higher risk of developing the disease $(3,4,5)$ obesity increases the risk of CRC by $19 \%$, while regu-

Corresponding author: Nataša Antoljak, School of Medicine, University of Zagreb and Croatian Institute of Public Health, School of Public Health 'Andrija Štampar', Rockefellerova 4, 10000 Zagreb, Croatia.

e-mail: natasa.antoljak@hzjz.hr lar physical activity reduces this risk by $24 \%$. The risk of CRC resulting from red meat intake is affected by overall intake and frequency (6). Consuming fish can reduce the risk of CRC by $12 \%$, while garlic intake is not significantly associated with a reduced risk of CRC (5). The intake of more than $20 \mathrm{~g} /$ day fiber is associated with a $25 \%$ lower risk of CRC, and $525 \mathrm{~mL} /$ day of milk reduces the risk by $26 \%$ in men. Moderate amounts of alcohol (25-30 g/day) increase the risk of CRC (5). As this type of cancer is mostly preventable, it is interesting to ask whether physical inactivity is an independent risk factor for developing CRC. It is necessary to prove an independent cause-and-effect relationship between an exposure factor and the occurrence of the disease (7). In this case, it is crucial to prove the independent connection between physical inactivity and CRC occurrence, i.e., to prove that it is not only a factor of indirect connection (confounding) on the actual causal path be- 
tween overweight, i.e., obesity and CRC (or other cancers). Also, it is essential to prove that either physical activity or obesity are not indirect linking factors while the real cause could be, for instance, unknown ingredients in a diet that are not harmful if taken in small amounts but are harmful in larger amounts (8). Obese people take more food and high-calorie drinks than they spend, so together with ingested, they also take larger amounts of such hypothetical ingredient(s). Furthermore, it is vital to determine the exposure to the causative factor, which could be quite demanding for researchers trying to prove this type of association. Most observational studies demonstrate a strong association between physical inactivity and disease, whereas intervention studies in which exposure factors change do not always result in a predicted change in disease incidence. This review paper aims to present a summary of the results published on this topic.

\section{METHODS}

We searched the Pubmed for manuscripts published in the last five years (2016-2020) with the following keywords: physical activity and colorectal cancer and all word reviews or meta-analysis fields. Forty-five papers were found. The same search was repeated without the words review or meta-analysis but marked as the review type, and 20 publications were found. After reviewing the obtained papers, those presenting the research results on the effects of obesity, physical activity, diet, smoking, and other known factors associated with a higher risk of colon cancer were included. The method of narrative review work was used, where a total of 28 papers were presented.

\section{RESULTS AND DISCUSSION}

Systematic research by Wang et al. from 2018 was produced after searching Medline, Embase, PsyInfo, Cochrane, and other databases and included 32 observational studies, out of which 17 were cross-sectional, ten case-control, and five cohorts (9). It concluded that in people with the highest level of physical activity, there was a $23 \%$ lower relative risk of any colon cancer (CRC) and $27 \%$ for advanced CRC than those with the lowest level of physical activity. In other words, physical activity was negatively associated with colon cancer of any type ( $\mathrm{n}=23$ studies) and advanced CRC ( $\mathrm{n}=15$ studies) (10). The relative risk obtained by meta-analysis was 0.77 for CRC and physical activity $(95 \% \mathrm{IP}=0.71-0.83, \mathrm{I} 2=57.5 \%)$, and advanced CRC $0.73(95 \% \mathrm{CI}=0.63-0.82, \mathrm{I} 2=45.5 \%)$. No association of physical activity with non-advanced CRC was found ( $\mathrm{n}=5$ studies). 10 There has been an association between physical activity and any type of CRC in both sexes and distal colon cancer. No publication bias was observed, which is very important when evaluating this type of research (10).

Extensive research by McTiernan et al., which included a review of 45 reports containing hundreds of epidemiological studies with several million participants, found a strong association between physical activity levels and reduced risk of cancer of the bladder, breast, colon, endometrium, esophagus, kidney and stomach (11). A relative risk reduction was found in the range of $10 \%$ to $20 \%$ (11). Based on 18 systematic reviews and meta-analyses, a moderate or limited association was found between more intense physical activity and reduced all-cause mortality and cancer-specific to individuals diagnosed with breast, colon, or prostate cancer, with a relative risk reduction of almost $40 \%$ to $50 \%$. An updated search, with five metaanalyses and 25 reviewed articles, confirmed these findings (11).

In the Alaska study, which began in 2003, out of the 3,712 people included in the follow-up, 171 $(4.7 \%)$ developed cancer by 2015 . A higher proportion of those who did not become ill had significant physical activity ( 45.1 vs. $33.3 \%, p=0.003$ ). The leading sites were breast cancer in women, lung and colon cancer, and colorectal cancer in both sexes. The incidence of all cancer sites was lower among those who had never smoked tobacco products (12).

The meta-analysis by Shen et al. (13) reported a significant association comparing the highest versus lowest amounts of sedentary behavior and combined colorectal cancer ( $R R=1.30$; 95\% CI:1.121.49); whereas Schmid and Leitzmann (14) reported a significant association for the highest versus lowest amounts of sedentary behavior and colon cancer (RR=1.28; 95\% CI: 1.13-1.45) but not for rectal cancer (RR=1.03; 95\% CI: 0.89-1.19). The International Agency for Research on Cancer (IARC), published in 2002, shows sufficient evidence of a 
causal relationship between overweight and inactivity with the incidence of colon cancer, but not rectal cancer (15). Since the causal relationship is best demonstrated when the pathogenesis is known, this is explained by the fact that abdominal obesity and physical inactivity cause insulin resistance and chronic hyperinsulinemia, which consequently reduces the concentration of IGF 1 and its binding proteins 1 and 2, which in turn increases tissue levels of IGF-1 and affects the onset and growth of cancer $(16,17,18)$. Another essential piece of evidence is the reduction of cancer risk in physically active people, and a possible mechanism includes shortening the passage of food through the digestive tract, which shortens the possible action of carcinogens in contact with mucous cells, immune system function, insulin production, and IGF, gene mutations and obesity prevention (18).

In a study of the Lebanese population in those with high physical activity, colon cancer incidence was $15 \%$ lower (19).

The biological underpinnings based on the association between physical activity and cancer risk have not been fully elucidated (20). The research of exercise has shown beneficial changes in circulating insulin concentrations, insulin-related pathways, and inflammation. A review by Kerr et al. (21) critically warned against caution in concluding about the pattern-consequential connection and the application of possible protective factors in intervention research. A review by EnnourIdrissi et al., which included 18 studies on the effect of exercise, concluded that physical activity could reduce oestradiol levels in women, whose exposure to high levels is a risk factor for breast cancer (22). The effects of physical activity or sedentary behavior, or both, on the immune system, epigenetics, protein translation, and microbiome, including the association with cancer development, are under active research $(23,24)$. The research on young adults has found that regular exercise has been linked to an enhanced immune response or surveillance, which is known to prevent cancer development (25).

In a prospective cohort study on a large population sample, physical activity was shown to be an independent factor associated with the development of colon cancer but not rectal cancer (26). In this study, however, the average follow-up time was short (2.7 years), and this was stated as a pos- sible methodological weakness of the study. This study is also consistent with a previous systematic review with a meta-analysis that included 30 studies and showed a negative association with cancer of all parts of the colon but not the rectum (27). An EPIC prospective cohort study included 366,521 women and 153,457 men aged 25 to 70 from 23 study centers in 10 European countries (sample collected and materials stored from 1992 to 2003). EPIC study proved that a high level of physical activity was associated with a lower risk of colon cancer (relative risk $\geq 91$ MET-hours/week compared to $<91$ MET-hour/week $=0.75(95 \%$ IP $=0.57$ to 0.96 ) found between waist circumference, a biomarker of the soluble leptin receptor, and 5-hydroxyvitamin $\mathrm{D}$ with the onset of colon cancer (28).

A large study of 13,057 nurses in the United States, aged 40-65, found that previous endoscopy, parental history of colorectal cancer, smoking, aspirin, animal fats, dietary fiber, folate, methionine and alcohol, physical activity was reversely associated with the risk of large $(>$ or $=1 \mathrm{~cm})$ adenomas in the distal part of the colon $(\mathrm{RR}=0.57$, IP 95\% 0.30-1.08) (29). Physical activity of moderate intensity, such as brisk walking, has proven to be a good preventative measure. In addition, BMI was directly associated with the risk of large adenomas in the distal colon (multivariate $R R=2.21$ $(\mathrm{CI}=1.18-4.16), \mathrm{P}=0.0001$, for $\mathrm{BMI}>$ or $=29 \mathrm{cf}<21$ $\mathrm{kg} / \mathrm{m} 2)(29)$.

In the case-control research on the sample of 788 participants, a healthy lifestyle index that included physical activity had a negative association with colorectal polyps $(\mathrm{OR}=0.72,95 \% \mathrm{IP}$ $0.62-0.85, \mathrm{P}<0.001)$, adenomas, and dentate polyps $(\mathrm{OR}=0,75,95 \%$ IP $0.64-0.89$ and $\mathrm{OR}=0.59$, 95\% IP 0.44-0.79), proximal and distal adenomas $(\mathrm{OR}=0.77,95 \%$ IP $0.62-0.95$, and $\mathrm{OR}=0.73,95 \% \mathrm{IP}$ $0.59-0.90)$ (30). Adherence to the $\geq 2$ components of a healthy lifestyle was strongly negatively associated with colorectal polyps $(\mathrm{OR}=0.50,95 \%$ IP 0.34-0.75, P = 0.001). Smoking abstinence and a healthy diet were the most strongly associated factors with lower coefficients of colorectal polyps $(\mathrm{OR}=0.58,95 \%$ IP $0.42-0.79$ and $\mathrm{OR}=0.61,0.44-$ 0.85). In a similar study, no negative association was found between CRC and physical activity and fiber-rich foods intake, and a positive association with cancer was found only for family history, obesity, and high-calorie foods (31). The results of a cohort study on a large sample from Norway, 
where almost 80,000 women were followed for 14.6 years, in which no statistically significant association of physical activity and CRC was obtained, shows how important it is to analyze the published works critically (32).

Lynch syndrome is caused by mutations in genes involved in the repair of DNA mismatch (MMR) (MLH1, MSH2, MSH6, and PMS2 and EPCAM). The estimated prevalence of this syndrome in the American population is 1: 280. In people with Lynch syndrome, the lifetime risk of developing endometrial cancer or colorectal cancer is high compared to the general population's risk. In a meta-study by Coletta et al. (33) already known risk factors have also been shown to affect the more common endometrial and colorectal cancers in people with Lynch syndrome. In another study, physical activity was expressed as the equivalent of metabolic activity, abbreviated MET. People with Lynch syndrome with the highest levels of physical activity (> 35 MET-h/week, which is $>10$ hours of brisk walking per week) had the lowest risk of colorectal cancer (34). The associations with physical activity during all age periods before or after the diagnosis of colorectal cancer were similar, although not significant by themselves. When investigating cancer that could be associated with possible exposures in a German sample of respondents aged 25-74, low physical activity contributed to endometrial, kidney, and lung cancer (population attributive risk fraction, $\mathrm{PAF}=15-19 \%$ ), and dietary factors mainly contributed to the development of colon, breast, and lung cancer (PAF=9$16 \%$ ) (35). A similar study conducted on the Lebanese population found that smoking was associated with most cases of cancer. Body mass calculated as an indicator of body mass (BMI) is associated with CRC and liver and stomach, especially in men. In people with high physical activity, the CRC rate is, on average, $15 \%$ lower. In both studies, the sample was small (36).

\section{CONCLUSION}

By reviewing the works published so far, physical activity contributes to the so-called healthy lifestyle and many other variables. There was no research in the papers regarding the mode of food production or other features of the available diet that could be associated with the emergence of CRC. In the works with a large number of respondents and several included variables and meta-analyses, different results were obtained mostly because of diverse methodology, which is a characteristic of meta-analyses. Physical inactivity is closely related to increased body weight. A few papers claim that neither of them is indirectly connected and that intense physical activity is a protective factor. The research question is burdened with other influences on the development of CRC (but also other malignant neoplasms) such as drugs, food additives or supplements, select products for athletes, the method of production of available foods, meat processing methods (natural or artificial smoking), diseases or conditions that can cause obesity. As far as physical activity is concerned, the actual activity can be more accurately measured than the anamnestic one, using modern tools. Although smoking tobacco products' effects on colon cancer development are significantly higher in the published papers, engaging in physical activity can contribute to the prevention of colon cancer.

\section{REFERENCES}

1. Šekerija M, Bubanović Lj, Čukelj P, Novak P, Lončar J, Štruc K et.al. Incidencija raka u Hrvatskoj 2017, Hrvatski zavod za javno zdravstvo, Zagreb, 2020. Bilten br. 42.

2. Čorić T, Erceg M, Mile Knežević A, Čukelj P. Izvješće o umrlima u 2017. godini, Hrvatski zavod za javno zdravstvo, Zagreb 2018:7.

3. Siegel RL, Torre LA, Soerjomataram I, Hayes RB, Bray F, Weber TK, et.al. Global patterns and trends in colorectal cancer incidence in young adults. Gut 2019;0:1-7. doi:10.1136/gutjnl-2019-319511

4. Vuik FR, Nieuwenburg SAV, Bardou M, LansdorpVogelaar I, Dinis-Ribeiro M, Bento MJ. Increasing incidence of colorectal cancer in young adults in Europe over the last 25 years.Gut2019;68:1820-826. doi. org/10.1136/gutjnl-2018-317592

5. Sung H, Siegel RL, Rosenberg PS, Jemal A. Emerging cancer trends among young adults in the USA: analysis of a population-based cancer registry. Lancet 2019; 4(3):E137-E147. doi:10.1016/S2468-2667(18)30267-6

6. Baena R, Salinas P. Diet and colorectal cancer. Maturitas 2015;80(3):258-64. doi:10.1016/j.maturitas.2014.12.017.

7. Kolčić I, Vorko Jović A. et.al. Epidemiologija, Medicinska naklada 2012, Zagreb

8. Cornish AJ, Tomlinson IPM, Houlston RS. Mendelian randomisation: A powerful and inexpensive method for identifying and excluding non-genetic risk factors for colorectal cancer. Molecular Aspects of Medicine 2019; https://doi.org/10.1016/j.mam.2019.01.002 
9. Wang J, Huang L, Gao Y, et al. Physically active individuals have a $23 \%$ lower risk of any colorectal neoplasia and a $27 \%$ lower risk of advanced colorectal neoplasia than their non-active counterparts: systematic review and meta-analysis of observational studies British Journal of Sports Medicine Published Online First: 11 July 2019; DOI: 10.1136/bjsports-2018-100350

10. Conti L, Del Cornò M, Gessani S. Revisiting the impact of lifestyle on colorectal cancer risk in a gender perspective. Crit Rev Oncol Hematol. 2020; 145:102834. https://doi: 10.1016/j.critrevonc.2019.102834. Epub 2019 Nov 18.

11. McTiernan A, Friedenreich K; Katzmarzyk P; Powell K, Macko R; Buchner D et al. Physical Activity in Cancer Prevention and Survival: A Systematic Review. Med Sci Sports Exerc 2019; 51(6): 1252-61. DOI: 10.1249/MSS.0000000000001937.

12. Nash SH, Day G, Zimpelman G, Hiratsuka Y, Koller KR. Cancer incidence and associations with known risk and protective factors: the Alaska EARTH study. Cancer Causes Control 2019; DOI:10.1007/s10552-01901216-9

13. Shen D, Mao W, Liu T, et al. Sedentary behavior and incident cancer: a meta-analysis of prospective studies. PLoS One. 2014;9(8):e105709. doi:10.1371/journal. pone.0105709.

14. Schmid D, Leitzmann MF. Television viewing and time spent sedentary in relation to cancer risk: a metaanalysis. J Natl Cancer Inst. 2014;106(7):pii:dju098. doi:10.1093/jnci/dju098.

15. IARC (2002). IARC Handbooks of Cancer Prevention, Volume 6. Weight control and physical activity. Lyon, France: IARC Press.

16. Bianchini F, Kaaks R, Vainio H. Overweight, obesity, and cancer risk. Lancet Oncol 2002; 3(9):565-74. DOI: 10.1016/S1470-2045(02)00849-5 PMID:12217794

17. Bianchini F, Kaaks R, Vainio H. Weight control and physical activity in cancer prevention. Obes Rev 2002; 3(1): 5 8. DOI:10.1046/j.1467-789X.2002.00046.x PMID: 12119660

18. Renehan AG, Tyson M, Egger M, Heller RF, Zwahlen $\mathrm{M}$ (). Body-mass index and incidence of cancer: a systematic review and meta-analysis of prospective observational studies. Lancet 2008; 371(9612): 569-78. DOI:10.1016/S0140-6736(08)60269-X PMID:18280327

19. Charafeddine M.A., Olson S.H., Mukherji D., Temraz S.N., Abou-Alfa G.K., Shamseddine A.I. Proportion of cancer in a Middle eastern country attributable to established risk factors. BMC Cancer 2017; 17(1):337. DOI:10.1186/s12885-017-3304-7

20. Ballard-Barbash R, Friedenreich CM, Courneya KS, Siddiqi SM, McTiernan A, Alfano CM. Physical activity, biomarkers, and disease outcomes in cancer survivors: a systematic review. J Natl Cancer Inst 2012; 104: 815-40.

21. Kerr J, Anderson C, Lippman SM. Physical activity, sedentary behaviour, diet, and cancer: an update and emerging new evidence. Lancet Oncol 2017; 18: e457-71
22. Ennour-Idrissi K, Maunsell E, Diorio C. Effect of physical activity on sex hormones in women: a systematic review and meta-analysis of randomized controlled trials. Breast Cancer Res 2015; 17: 139.

23. Hibler E. Epigenetics and colorectal neoplasia: the evidence for physical activity and sedentary behavior. Curr Colorectal Cancer Rep 2015; 11: 388-96.

24. Robinson MM, Dasari S, Konopka AR, et al. Enhanced protein translation underlies improved metabolic and physical adaptations to different exercise training modes in young and old humans. Cell Metab 2017; 25: 581-92.

25. Zheng Q, Cui G, Chen J, et al. Regular exercise enhances the immune response against microbial antigens through up-regulation of toll-like receptor signaling pathways. Cell Physiol Biochem 2015; 37: 735-46.

26. Nunez C, Nair-Shalliker V, Egger S, Sitas F, Bauman A. Physical activity, obesity and sedentary behaviour and the risks of colon and rectal cancers in the 45 and up study. BMC Public Health. 2018;18(1):325. doi: 10.1186/s12889-018-5225-z.

27. Trude E R, Bjarte A, Anette H, Hilde L, Bray FI, Inger IK. Body mass index, physical activity, and colorectal cancer by anatomical subsites: a systematic review and meta-analysis of cohort studies. Eur J Cancer Prev 2013; 22(6):492-505.

28. Aleksandrova K, Jenab M, Leitzmann M, BuenodeMesquita B, Kaaks R, Trichopoulou A et al. Physical activity, mediating factors and risk of colon cancer: insights into adiposity and circulating biomarkers from the EPIC Cohort. Int J Epidemiol 2017; 46(6): 1823-1835. DOI:10.1093/ije/dyx174

29. Giovannucci E, Colditz GA, Stampfer MJ, Willett WC. Physical activity, obesity, and risk of colorectal adenoma in women (United States). Cancer Causes Control 1996;7(2):253-63.

30. Fliss-Isakov N, Kariv R, Webb M, Ivancovsky-Wajcman D, Zaslavsky O, Margalit D, Shibolet O, ZelberSagi S. A healthy lifestyle pattern has a protective association with colorectal polyps. Eur J Clin Nutr 2019; Jul 30. doi: 10.1038/s41430-019-0481-2.

31. Mafiana RN, Al Lawati AS, Waly MI, Al Farsi Y, Al Kindi M, Al Moundhri M. Association between Dietary and Lifestyle Indices and Colorectal Cancer in Oman: A Case-Control Study. Asian Pac J Cancer Prev 2018; 19(11):3117-3122

32. Oyeyemi SO, Braaten T, Licaj I, Lund E, Benjaminsen Borch K. Physical activity patterns and the risk of colorectal cancer in the Norwegian Women and Cancer study: a population-based prospective study. BMC Cancer 2018; 18(1):1216. doi: 10.1186/s12885-018-5092-0.

33. Coletta AM, Peterson SK, Gatus LA, Krause KJ, Schembre SM, Gilchrist SC, et.al. Energy balance related lifestyle factors and risk of endometrial and colorectal cancer among individuals with lynch syndrome: a systematic review. Familial Cancer DOI: 10.1007/s10689-019-00135-7 
34. Dashti SG, Win A K, Hardikar SS, Glombicki SE, Mallenahalli $S$, Thirumurthi $S$, et al. Physical activity and the risk of colorectal cancer in Lynch syndrome. International Journal of Cancer 2018; DOI: 10.1002/ijc.31611

35. Behrens G, Gredner T, Stock C, Leitzmann MF, Brenner H, Mons U. Cancers Due to Excess Weight, Low Physical Activity, and Unhealthy Diet. Dtsch Ar- ztebl Int 2018; 115(35-36): 578-85. doi: 10.3238/arztebl.2018.0578.

36. Charafeddine MA, Olson SH, Mukherji D, Temraz SN, Abou-Alfa GK, Shamseddine AI. Proportion of cancer in a Middle eastern country attributable to established risk factors. BMC Cancer 2017; 17(1):337. doi: 10.1186/ s12885-017-3304-7.

Sažetak

\section{ZNAČAJNOST TJELESNE AKTIVNOSTI U SPRJEČAVANJU RAKA DEBELOG CRIJEVA}

\section{N. Antoljak}

Rak debelog i završnog crijeva je po pojavnosti drugo sijelo među zloćudnim novotvorinama kao i po smrtnosti od zloćudnih novotvorina u oba spola. Od ove bolesti u Republici Hrvatskoj oboljelo je u 2017. godini 3659 osoba, a umrlo 2095 osoba u 2019. godini. Rak debelog crijeva preventabilan je, a od poznatih činitelja koji utječu na nastanak su pušenje i debljina. U tijesnoj vezi s debljinom je tjelesna neaktivnost te se postavlja pitanje može li tjelesna neaktivnost biti neovisni prediktor za rak debelog crijeva. S ciljem uvida u dosadašnja istraživanja pretražena je dostupna literatura u bazi Pubmed posljednjih 5 godina, uključivši sustavne preglede i metaanalize o povezanosti tjelesne aktivnosti i pojavnosti raka debelog crijeva. Istraživanja su metodološki raznolika a uključuju i različite pristupe. U većini opservacijskih istraživanja veća tjelesna aktivnost povezana je s nižom pojavnošću raka debelog crijeva. U intervencijskim istraživanjima dobiveni su različiti rezultati. Općenito, znatno veći učinak na nastanak raka debelog crijeva ima pušenje duhanskih proizvoda, no bavljenje tjelesnom aktivnosti povezano je s pojavom te bolesti te treba biti jedna od mjera prevencije.

KLJUČNE RIJEČI: rak debelog crijeva, tjelesna aktivnost, uzročno posljedična povezanost 